\title{
İşletmelerin, Tüketici Tarafından Algılanan Sosyal Medya Çabalarının (Aktivitelerinin) Marka Tercihine Etkisinde Markaya Duyulan Güvenin Aracılık Etkisi: GSM Sektöründe Bir Uygulama
}

Zafer CESUR*

Salih MEMIŞ**

$\ddot{O} z$

Teknolojik gelişmeler, bireylerin yaşantısı, kişiler ve işletmeler arası iletişim, haberleşme, dağıtım ve ulaşım kanalları gibi işleyişlerinin değişmesine sebebiyet vermiştir. Özellikle iletişim alanında yaşanan değişimler bireyler arası etkileşimin boyutunu ve biçimini değiştirmiştir. Bu iletişim alanında yaşanan en önemli değişimin başında da her geçen gün artan sosyal medya kullanımı gelmektedir. Sosyal medya ağları ilk önce bireylerin birbirleri ile haberleşmesini sağlayan alanlar olarak faaliyet göstermekte iken, yaşanan gelişmelerle birlikte işletmelerin mal ve hizmetlerine yönelik sosyal medya çabaları içerisinde bulunduğu bir alan olarak da yeni bir boyut kazanmıştır. Bu çalışmada, işletmelerin sosyal medya üzerinden gerçekleştirdiği pazarlama çabalarının markaya duyulan güven ve marka tercihi üzerindeki etkisinin ortaya koyulması amaçlanmıştır. Yapılan araştırma sonucunda tüketicilerin algıladıkları sosyal medya pazarlama çabalarının tüketicilerin markaya duydukları güven üzerinde anlamlı ve pozitif etkisi olduğu tespit edilmiştir. Ayrıca tüketicilerin algıladıkları sosyal medya pazarlama çabalarının, tüketicilerin markaya duydukları güven düzeyi üzerinden (aracılık etkisi) marka tercihi üzerinde anlamlı bir etkisi olduğu saptanmıştır.

Anahtar Kelimeler: Sosyal Medya, Marka Tercihi, Markaya Duyulan Güven, GSM Sektörü.

\section{Mediating Effect of Trust in the Brand in the Effect of Social Media Efforts (Activities)Perceived by the Consumer on Brand Preference: An Application in the GSM Sector}

\begin{abstract}
Technological developments have led to changes in the life of individuals, communication between individuals and businesses, communication, distribution and transport channels. Changes, especially in the field of communication, have changed the size and form of interpersonal interaction. At the beginning of the most important change in this field of communication is the increasing use of social media every day. First social media networks, operates as fields that enable individuals to communicate with each other, while with recent developments within the social media efforts of businesses for goods and services has gained a new dimension as an area where it is located. In this study, it was aimed to demonstrate the impact of marketing efforts carried out by businesses through social media on brand confidence and brand preference. As a result of the research, it was found that the social media marketing efforts perceived by consumers have a significant and positive effect on consumers ' confidence in the brand. In addition, it was found that social media marketing efforts perceived by consumers have a significant effect on brand preference over the level of trust consumers have in the brand (brokerage effect).
\end{abstract}

Keywords: Social Media, Brand Preference, Brand Confidence, GSM Sector.

Geliş/Received: 04.08 .2021

Kabul/Accepted: 27.12 .2021

- $\mathrm{Bu}$ çalışma için, Giresun Üniversitesi Sosyal Bilimler Fen ve Mühendislik Bilimleri Araştırmaları Etik Kurulu'nun 02.06.2021 tarih ve 11/10 sayılı kararı ile etik kurul izni alınmıştır.

\footnotetext{
* Öğr. Gör., Kocaeli Üniversitesi, İsmet Uzunyol MYO, Yönetim ve Organizasyon, zafer.cesur@kocaeli.edu.tr, ORCID:0000-0002-5758-7688

** Doç. Dr., Giresun Üniversitesi, Bulancak Kadir Karabaş UBYO, Lojistik Yönetimi, Salih.memis@giresun.edu.tr, ORCID:0000-0003-1345-3618

(Makale Türü: Araştırma Makalesi)
} 


\section{Giriş}

İşletmeler, yapacakları pazarlama araştırmalarıyla beraber pazardaki tüketicilerin istek, ihtiyaç ve satın alma güçlerini tespit etmeli ve bunları göz önünde bulundurarak kalite özelliklerini belirlemelidirler (Usta ve Memiş, 2009: 102). Bu nokta sosyal medya platformu işletmelere gereken kolaylığı sağlamada çok önemli bir rol üslenmektedir.

Sosyal medya, her geçen gün önemini arttırmaya başladığından ve tüm dünyada çı̆̆ gibi büyüdüğünden dolayı, daha karmaşık bir duruma bürünmeye başlamıştır. Sosyal medyanın artan şöhreti nedeniyle organizasyonlar, sosyal medyanın nasıl kullanılacağı ve nasıl yönetilmesi gerektiğine yönelik faaliyetler yürütmeye başlamışlardır (Di Satso vd., 2011: 325).

Sosyal medya bireylerin birbirleri ile iletişim kurmasını sağlayan bir alan iken yaşanan teknolojik gelişmelerin de etkisiyle işletmelerin pazarlama çabaları için içerik oluşturmasına olanak sağlamıştır. Özellikle sosyal medyanın ortaya çıkışı, kullanıcıların yoğun ilgi göstermesi bulunması, işletmelerin ve kurumların bu mecraya yönelmesine neden olmuştur. Geleneksel medya araçlarının sunmuş olduğu dar ve kısıtlı imkanlar, sosyal medyanın gelişiminde de hızlanma meydana getirmiştir.

İşletmeleri sosyal medya araçlarına yönelten bir başka unsur da küreselleşmenin ortaya çıkardığı rekabet koşullarında varlığını sürdürebilme ve rakiplerinden farklılaşma isteği olmuştur. Özellikle Facebook, Instagram, Twitter ve Youtube vb. sosyal medya alanlarına tüketicilerin yoğun bir ilgi göstermesiyle birlikte kullanıcı sayılarının ve bu alanlarda geçirilen sürelerin giderek artması, işletmeler için inanılmaz firsatlar oluşturmaktadır.

İşletmelerin pazarlama çabalarını sosyal medya alanlarına taşımasıyla sosyal medyada reklam, tanıtım, satış ve kurumsal iletişim gibi tutundurma çabalarının kullanılması, sosyal medyanın önemini daha da artmasını sağlamıştır. Bundan dolayı sosyal medya bir sektör olarak görülmeye başlanmış ve her geçen gün bu sektörde faaliyet gösteremeyen işletmeleri bu alana yöneltmiştir. Bununla birlikte doğru bir sosyal medya çabanın oluşturulabilmesi için işletmeler, sosyal medyanın nasıl kullanılması ve yönetiminin nasıl olması gerektiği sorusuna yanıt aramaya başlamıştır. Sosyal medya ağlarında faaliyet gösteren işletmelerin, kurumların, sayısının her geçen gün artması ile bu işletmelerin sosyal medya ile alakalı pazarlama çabalarını doğru bir şekilde oluşturarak rekabet koşullarında varlığını sürdürebilme ve rakiplerinden farklılaşmayı sağlayabilmesi önemli bir husustur. Dolayısıyla işletmelerin sosyal medya üzerinden gerçekleştirdiği pazarlama çabalarının tüketiciler üzerindeki etkisini belirlemek önem arz etmektedir.

Çalışmada sosyal medya üzerinden yürütülen pazarlama çabalarının markaya duyulan güven ve marka tercihi üzerindeki etkisinin ortaya konulması amaçlanmıştır. Ayrıca bu etkinin doğrudan ve dolaylı (aracılık) etkilerinin tespit edilmesi araştırmanın diğer amacını oluşturmaktadır. Bu amaçla 
öncelikli olarak çalışmada yer alan değişkenler (markaya duyulan güven ve marka tercihi) kavramsal olarak ele alınarak incelenmiştir. Daha sonra internette sosyal medyayı kullanan ve GSM operatörü şirketlerin (Vodafone, Turkcell ve Türk Telekom) sosyal medya hesaplarını takip eden tüketicilere yönelik anket yöntemi ile verilerek toplanarak analiz edilmiş ve elde edilen bulgular sonuç bölümünde tartışılmıştır.

Çalışmanın işletmelerin uyguladığı sosyal medya çabalarının tüketiciler tarafından algılamalarının araştııılması açısından marka tercihi ve markaya duyulan güven değişkenlerini barındırması ve hizmet alanında GSM sektörü üzerinde uygulamanın yapılması aynı zamanda alandaki sınırlı sayıdaki çalışmalardan biri olması sebebi ile literatüre katkı sağlayacağı düşünülmektedir.

\section{Literatür İncelemesi}

\section{Algılanan Sosyal Medya Pazarlama Çabaları}

İşletmeler marka bağlılı̆g geliştirerek rekabet üstünlüğü elde etmeyi amaç edinmektedirler (Memiş ve Cesur, 2016: 453). Bu noktada hedef kitleyle iletişim halinde olmak önemli bir unsurdur.

İşletmelerin mal ve hizmetlerini tutundurma çabalarını gerçekleştirmesi amacıyla sosyal medya günümüzde kullanılan en önemli bir pazarlama iletişimi öğesi olarak adlandırılmaya başlanmıştır. Zira insanlar günlük haberleri, çevresindeki kişilerin neler yaptığını öğrenmek, kendi yaptıklarını da çevreye haberdar edebilmek adına bu ortamı sıklıkla kullanmaktadırlar. Bunun sonucu olarak da işletmeler/markalar bireylerin sık sık online olup zamanlarının büyük bir kısmını geçirdikleri sosyal ağ ortamlarında mal ve hizmetlerini tutundurma çabalarına girmektedirler (Göktaş ve Tarakçı, 2018: 63).

Sosyal medya pazarlama çalışmaları, genellikle işletmelerin sosyal medya araçlarıyla gerçekleştirdiği çeşitli pazarlama faaliyetleridir. Tüketiciler tarafından sosyal medyanın yoğun kullanımı markaların sosyal medya pazarlama çalışmaları her geçen gün önem kazanmaktadır (Karayalçın, 2019: 20). Sosyal medya pazarlama çalışmalarının, markalaşma hedeflerine ulaşmak için geleneksel pazarlama çabalarına aynı düzeyde veya daha fazla katkı sağlama potansiyeline sahip olduğu da söylenebilir (Godey vd., 2016: 5839).

Kim ve Ko (2012), markanın mal ve hizmetlerini bir pazarlama iletişimi aracı olarak tanıtmak veya markanın kendisini tüketicilere tanıtmak gibi sosyal medya pazarlama çalışmalarının özelliklerinden bahsetmektedir.

Kim ve Ko (2012), algılanan sosyal medya pazarlama çabalarının beş farklı boyuttan (eğlence, etkileşim, moda, kişilik ve ağızdan ağza) oluştuğunu belirtmektedir.

Literatürde sosyal medya pazarlama çalışmalarının Kim ve Ko (2012)' nun makalesine göre beş boyutta tartışıldığı ve bu çalışmada sosyal medya pazarlama çalışmalarının eğlence, etkileşim, moda, kişilik ve ağızdan ağza ve tüketici algısı düzeyinde değerlendirildiği görülmektedir. 


\section{Markaya Duyulan Güven}

Güven, sosyal alışverişin bir bileşenidir. Markaya duyulan güvenin, markaların elde edeceği başarı düzeyinde pazarlama literatüründe çok önemli olduğu görülmüştür (Morgan ve Hunt, 1994: 2230). Bununla birlikte güven, "güven hedefinin algılanan dürüstlügü, yeterliliği ve faydası" biçiminde ifade edilmektedir (Coulter ve Coulter, 2002: 37). Güven aynı zamanda "başka bir kelimeye ve olumlu davranış beklentisine dayalı olarak savunmasızlığı kabul etme niyetini kapsayan psikolojik bir hal" olarak tanımlamıştır.

Chaudhuri ve Holbrook (2001: 82) marka güvenini "tüketicilerin markanın fonksiyonunu ifa etme yeteneğine inanma istekliliği” olarak tanımlamıştır. Disiplinler arasında güvenin belirsiz ve riskli bir varsayım olduğuna dair ortak bir fikir birliği söz konusudur.

Delgado-Ballester ve Munuera-Aleman'a (2005: 190) göre marka güvencesinin iki boyutu bulunmaktadır. İlk boyut (güvenilirlik), verilen sözleri ifa etme ve müşterilerin hesap verebilirliğini karşılama becerisi ve istekliliğini kapsayan teknik ya da yetkinlik tabanlı bir özelliktir. İkinci boyut (niyetler), ürünle ilgili beklenmedik sorunlar ortaya çıktı̆̆ında, iyi niyet tüketicilerinin "menfaatleri ve iyiliği" nin marka ile sözlü olarak ilişkilendirilmesini içermektedir. Bu nedenle güvenilir bir marka; üretimi, satışı, servisi ve reklamı ile tüketiciye verdiği sözleri sürekli sürdüren bir markadır.

Güven, risk karşısında diğer tarafa inanma istekliliğini ifade eder. Bu talep karşı tarafın geçmiş deneyimlerinden kaynaklanmaktadır. Karşı taraf için olumsuz sonuçlar doğuran güven, sadece kişi için olumlu bir sonuç oluşturmaktadır (Lau ve Lee, 1999: 343). Kendilerine uygun bir tüketici grubu belirleyip edindikten sonra işletmeler bu tüketiciler ile güçlü ilişkiler geliştirmeye başlamakta ve güvenle araştırma yapmaktadır (Bennet, 1996: 421). Tüketici grubu ile böylelikle kendi aralarında güven duygusu kazanmış işletmeler diğer rakip rakiplere göre avantaj elde etmektedirler (Chaudhuri ve Holbrook, 2001: 82).

\section{Marka Tercihi}

Tüketiciler satın almada karar karmaşıklığını azaltmak amacıyla marka tercihi oluşturmaktadırlar (Hwang ve Chihyung, 2013: 125). Tüketicilerin marka tercihi üç boyuttan (bilişsel, duyusal ve davranışsal) oluşmaktadır (Bartels ve Jhonson, 2015: 48).

Marka tercihi, tüketicilerin alışkanlıklarına veya deneyimlerine göre rakiplerin marka seçme davranışları olarak ifade edilebilir (Aktuğlu ve Temel, 2006: 45). Marka tercihi, belirli bir markanın rekabetçi tüketici tarafindan seçilmesi olarak kavramsallaştırılabilir (Punj ve Hillyer, 2004: 127). Marka seçim süreci, birçok marka için marka seçimiyle biten karmaşık olan bir satın alma karar sürecidir (Roberts ve Lattin, 1991: 435). 
Tüketiciler belirli bir markayı tercih etmekte; tüketici gereksinimlerinin nitelikleri, marka imajı, tüketici algıları, pazarlama faaliyetlerinin etkinliği, sosyal, psikolojik, kişisel ve çevresel faktörler gibi birçok farklı neden vardır (Keskin ve Yıldız, 2010: 240).

İşletmelerin pazarda başarılı olabilmeleri için marka tercihlerini neyin etkilediğini saptamaları önemlidir (Cesur ve Alnıaçık, 2019: 3486). Bu nedenle marka tercihini anlamak, özellikle marka tercihini geliştirmek ve bu değişkenlerin sonuçlarını irdelemek gerekir (Mathur, Moschis ve Lee, 2003: 133).

Marka tercihi büyük oranda önceki müşteri tecrübelerine bağlı olarak şekillenmektedir (Keiningham vd., 2005: 175). Diğer bir ifadeyle, pozitif bir müşteri deneyimi, müşterinin bir marka için bir tercih oluşturmasını sağlar (Hellier vd., 2003: 1770). Tüketici tutumları, ürün ve/ veya hizmetlerinin tüketiminden sonra markaları değerlendirmekten kaynaklanmaktadır.

\section{Araştırma Metodolojisi}

\section{Araştırmanın Amacı}

$\mathrm{Bu}$ araştırmanın amacı; sosyal medya üzerinden yapılan pazarlama aktivitelerinin markaya duyulan güven ve marka tercihi üzerindeki etkisini ortaya koymaktır. Ayrıca bu etkinin doğrudan ve dolaylı (aracılık) etkilerinin tespit edilmesi araştırmanın diğer amacını oluşturmaktadır. Giresun üniversitesi ve Kocaeli Üniversitesi öğrencileri üzerinde bir alan araştırması gerçekleştirilmiştir. İnternette sosyal medyayı kullanan ve GSM operatörü şirketlerin (Vodafone, Turkcell ve Türk Telekom) sosyal medya hesaplarını takip eden anket yöntemi ile veri toplanmıştır. Araştırma, Şubat-Mart 2021 tarihleri arasında kolayda örneklem yoluyla belirlenmiş öğrencilere çevrimiçi ankete davet daveti gönderilerek belirtilen kontrol sorularının ile kısıtlamalar gerçekleştirilerek uygulama yapılmıştır.

\section{Araştırmanın Örneklem ve Veri Toplama Yöntemi}

Araştırmada kolayda örneklem yöntemiyle ulaşılan 238 kişiye anket uygulanmıştır. Kolay örnekleme yönteminde örneklem seçimi öznel olduğu için genelleme problemleri yaşanmaktadır (İslamoğlu ve Alnıaçık, 2016: 42). Araştırmada zaman, maliyet kısıtlarından dolayı kolaylama örnekleme yöntemi seçilmiştir.

Araştırmada kullanılan anket formu iki bölümden oluşmaktadır. İlk bölümde demografik özellikler hakkında sorular bulunmaktadır. İkinci bölümde; algılanan sosyal medya pazarlama çabaları ölçeği kullanılmıştır. Çalışmada markaların sosyal medya üzerinden yaptığı pazarlama çabaları tüketicilerin algılamaları 1şığında ölçülecektir. Literatürde sosyal medya pazarlama çabalarının çeşitli boyutlar ile ölçüldüğü gözlemlenmektedir. Örneğin, Kim ve Ko (2012) sosyal medya pazarlama çabalarını geliştirdiği ölçek ile eğlence, etkileşim, moda, kişisellik ve kulaktan kulağa iletişim şeklinde 5 boyutu ile ölçmüştür. Bu çalışma kapsamında da sosyal medya pazarlama çabaları Kim ve Ko (2012)' nun kavramsallaştırdığı şekilde eğlence, etkileşim, moda, kişisellik ve kulaktan kulağa iletişim boyutu 
ile değerlendirilmiştir. Bu bağlamda sosyal medya üzerinden yapılan pazarlama çabalarını ölçen boyutlar ve ifadeler Kim ve Ko (2012) makalesinden adapte edilerek hazırlanmıştır. Araştırmada markaya duyulan güven Markaya duyulan güven ölçeği ile ölçülmüştür. Marka güveni ve marka sadakati ile ilgili ifadeleri bir arada kapsayan Delgado ve Munuera (2005) çalışmasından alınmıştır. Şahin ve Gültekin (2017:995-1001) ve Horppu vd (2008: 405) çalışmalarında da kullanılmıştır. Araştırmada marka tercihini belirlemeye yönelik olarak Marka tercihi ölçeği kullanılmıştır. Marka tercihi ölçeği için Chang ve Liu (2009: 1690)'nun geliştirdiği 4 ifadeli ölçek, kullanılmıştır. Cevaplar 5'li Likert ölçeğinde alınmıştır ( $1=$ Kesinlikle Katılmıyorum, 5 = Kesinlikle Katıllıorum). Anket hazırlandıktan sonra, 30 üniversite öğrencisi üzerinde test edilmiştir.

\section{Araştırmanın Modeli ve Hipotezler}

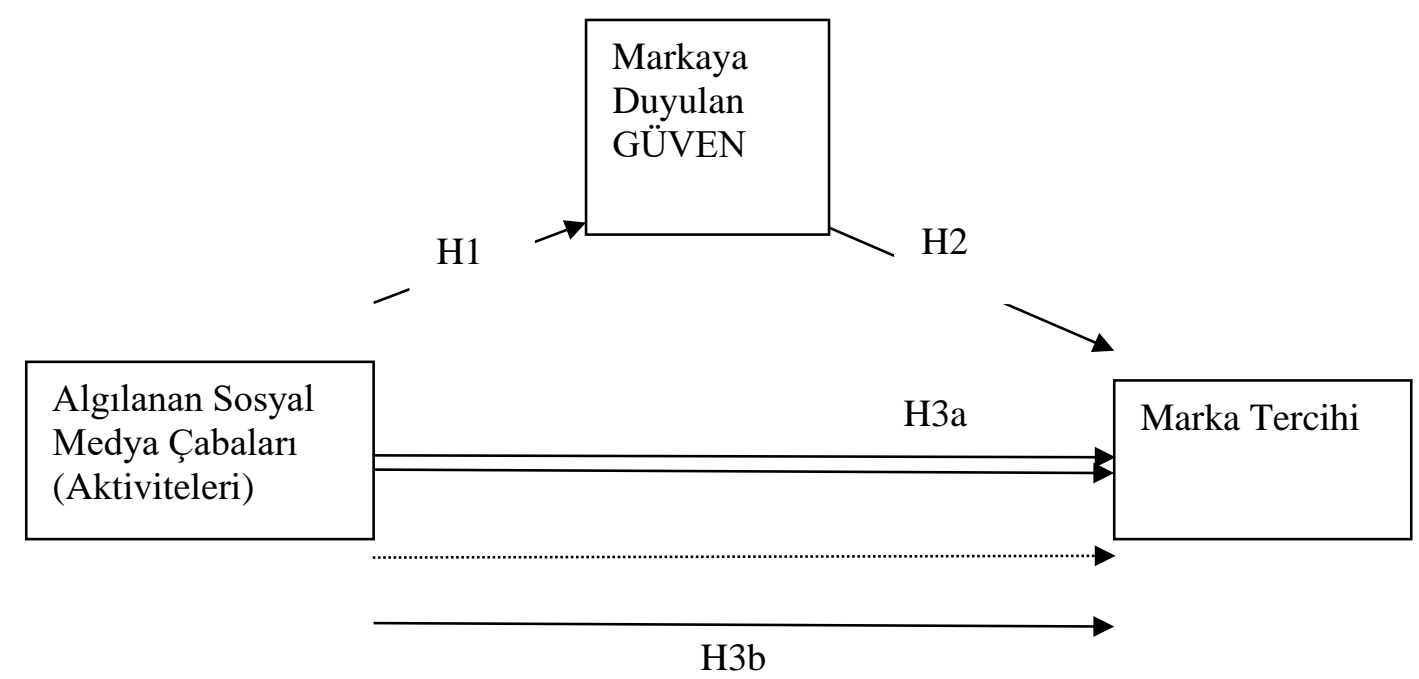

Şekil 1: Araştırmanın teorik modeli

Araştırma modelini ve araştırma modelindeki etkileri test etmek için PLS yapısal eşitlik modellemesi kullanılmıştır. Analizlerde SPSS 25 ve Smart-PLS 3.3.2 programı kullanılmıştır.

Sosyal medya çabalarının marka imajı boyutlarından müşteri değeri, yenilik ve farkındalık, kalite ve fiyat boyutlarının marka güveni üzerinde pozitif yönlü bir ilişki göstermesi beklenmektedir (Haciefendioğlu ve Fırat, 2014: 89). Dolayısıyla tüketicilerin algıladıkları sosyal medya pazarlama çabalarının tüketicilerin markaya duydukları güven üzerinde anlamlı ve pozitif pozitif yönlü bir etki göstermesi beklenmektedir Buradan hareketle $\mathbf{H 1}$ hipotezi geliştirilmiştir.

H1: Tüketicilerin algıladıkları sosyal medya pazarlama çabalarının tüketicilerin markaya duydukları güven üzerinde anlamlı ve pozitif etkisi vardır.

Marka güveninin marka sadakati ve marka tercihinin sağlanmasına yönelik önemli ve ortak bir bileşen olduğu düşünülmektedir (Chaudhuri ve Holbrook, 2001: 82; Chang ve Liu, 2009: 1690; Önen, 
2018: 615). Dolayısıyla tüketicilerin markaya duydukları güven düzeyinin marka tercihi üzerinde pozitif yönlü bir etki göstermesi beklenmektedir Buradan hareketle $\mathbf{H 2}$ hipotezi geliştirilmiştir.

H2: Tüketicilerin markaya duydukları güven düzeyinin marka tercihi üzerinde anlamlı ve pozitif etkisi vardır.

Sosyal medya çabalarının tüketicilerin marka tercih üzerinde olumlu etki göstermesi beklenmektedir (Godey vd., 2016: 5835; Uzunkaya ve Yükselen, 2020: 280). Dolayısıyla Tüketicilerin algıladıkları sosyal medya pazarlama çabalarının marka tercihi üzerinde pozitif yönlü bir etki göstermesi beklenmektedir. Diğer taraftan, markaya duyulan güvenin bu etkide aracılık etkisi göstereceği öngörülmüştür.

Buradan hareketle $\mathbf{H 3}$ hipotezi geliştirilmiştir.

H3: Tüketicilerin algıladıkları sosyal medya pazarlama çabalarının marka tercihi üzerinde anlamlı ve pozitif etkisi vardır.

H3a: Tüketicilerin algıladıkları sosyal medya pazarlama çabalarının marka tercihi üzerinde anlamlı, pozitif ve direkt bir etkisi vardır.

H3b: Tüketicilerin algıladıkları sosyal medya pazarlama çabalarının Tüketicilerin markaya duydukları güven düzeyi üzerinden (Aracılık Etkisi) marka tercihi üzerinde anlamlı bir etkisi vardır.

\section{Araştırma Bulguları}

\section{Demografik ve Diğer Bulgular}

Ankete katılan cevaplayıcılar, \%10,5'i 19-26 yaş, \%75,6’1 19-26 yaş ve \%13,9'u 27 yaş ve üzeri yaş aralığında bulunmaktadır. Ankete katılanların \%61,3’ü kadın, \%38,7’i erkektir. Bunların \%16,8’i evli iken, \%83,2'i bekârdır. Cevaplayıcıların şuan almış oldukları eğitim düzeyine bakıldığında, \%53,7' si önlisans, \%43,9’u lisans, ve \%3,4'ü lisansüstü eğitim almaktadırlar. Ankete katılan cevaplayıcıların aile aylık gelir seviyeleri değerlendirildiğinde \%28,6'i 0-2800TL, \%45,8'i 1801-5600TL, \%16,8'ü 5601-8400TL ve \%8,8'ü 8401TL ve üzeri gelire sahiptir.

Araştırmaya katılanların günlük ortalama sosyal medyada geçirdikleri süreler incelendiğinde cevaplayıcıların \%10,9'u günde 1 saatten az, \%42,9'u günde 2-4 saat, \%33,6'1 günde 5-7 saat ve \%13,0'1 günde 8 saat ve üzeri zaman geçirmektedirler. Yine cevaplayıcıların GSM operatörlerinden hangisinin sosyal medya hesaplarını en çok takip etmekte oldukları sorusuna verdikleri cevaplar incelendiğinde cevaplayıcıların \%28,9'u Vodafone şirketinin sosyal medya hesabını, \%36,9'u Turkcell şirketinin sosyal medya hesaplarını ve \%34,2'i ise Türk Telekom şirketinin sosyal medya hesaplarını takip ettiği görülmektedir.

\section{Açıklayıcı Faktör Analizi ve Güvenilirlik Analizi}


Araştırmada kullanılan ölçeklerin geçerliliğini belirlemek için açıklayıcı faktör analizi ve ölçeklerin güvenilirliği test etmek için ise, Cronbach's Alpha katsayısı hesaplanmıştır. Tablo 1 de araştırmada kullanılan ölçeklere ait açıklayıcı faktör analizi sonuçları ve ölçeklerin güvenilirlik sonuçlarına yer verilmiştir.

Tablo 1: Araştırmada kullanılan ölçeklere ait açıklayıcı faktör analizi sonuçları ve ölçeklerin güvenilirlik sonuçları

\begin{tabular}{|c|c|c|c|c|c|c|}
\hline & Ortalama & $\begin{array}{c}\text { Std. } \\
\text { Sapma }\end{array}$ & \begin{tabular}{c|c|} 
Faktör \\
Yük
\end{tabular} & $\begin{array}{c}\text { Öz } \\
\text { değer }\end{array}$ & $\begin{array}{l}\text { Açıklanan } \\
\text { Varyans \% }\end{array}$ & $\begin{array}{c}\text { C- } \\
\text { Alpha }\end{array}$ \\
\hline \multicolumn{7}{|c|}{$\begin{array}{l}\text { ALGILANAN SOSYAL MEDYA PAZARLAMA ÇABALARI/AKTIVITTELERİ (KMO:0,930) } \\
\text { (Bartlett's/Chi-Square:2127,08 Sig:0,000) }\end{array}$} \\
\hline $\begin{array}{l}\text { X markasının sosyal medyasında } \\
\text { vakit geçirmek eğlencelidir }\end{array}$ & 2,9958 & 1,34226 & ,813 & \multirow{11}{*}{7,281} & \multirow{11}{*}{66,20} & \multirow{11}{*}{0,949} \\
\hline $\begin{array}{l}\text { X markasının sosyal medya } \\
\text { içerikleri ilgi çekicidir }\end{array}$ & 3,0294 & 1,27421 & ,869 & & & \\
\hline $\begin{array}{l}\text { X markasının sosyal medyası } \\
\text { başkaları ile bilgi paylaşımına } \\
\text { olanak sağlar }\end{array}$ & 3,1849 & 1,29892 & ,827 & & & \\
\hline $\begin{array}{l}\text { X markasının sosyal medyası } \\
\text { yoluyla başkalarıyla sohbet veya } \\
\text { fikir değişimi yapmak mümkündür }\end{array}$ & 3,2185 & 1,32906 & 847 & & & \\
\hline $\begin{array}{l}\text { X markasinın sosyal medyası } \\
\text { yoluyla fikirlerimi kolayca } \\
\text { paylaşabilirim }\end{array}$ & 3,1849 & 1,31185 & ,848 & & & \\
\hline $\begin{array}{l}\text { X markasının sosyal medyasındaki } \\
\text { içerikler en yeni bilgileri içerir }\end{array}$ & 3,1471 & 1,28584 & 801 & & & \\
\hline $\begin{array}{l}\text { X markasinın sosyal medyası } \\
\text { modaya uygundur }\end{array}$ & 3,3109 & 1,26456 & ,814 & & & \\
\hline $\begin{array}{l}\text { X markasının sosyal medyası kişiye } \\
\text { özel bilgi sunar }\end{array}$ & 2,9412 & 1,25818 & ,759 & & & \\
\hline $\begin{array}{l}\text { X markasının sosyal medyası kişiye } \\
\text { özel hizmet sağlar }\end{array}$ & 3,0420 & 1,25886 & ,779 & & & \\
\hline $\begin{array}{l}\text { X markasının sosyal medyasında yer } \\
\text { alan marka, ürün veya hizmetler ile } \\
\text { ilgili bilgileri arkadaşlarıma iletmek } \\
\text { isterim }\end{array}$ & 2,9706 & 1,29066 & ,824 & & & \\
\hline $\begin{array}{l}\text { X markasının sosyal medya } \\
\text { içeriklerini kendi blog veya } \\
\text { hesaplarıma yüklemek isterim }\end{array}$ & 2,7143 & 1,34474 & ,760 & & & \\
\hline \multicolumn{7}{|c|}{ MARKA TERCIHİ (KMO:0,788) (Bartlett's/Chi-Square:502,02 Sig:0,000) } \\
\hline $\begin{array}{l}\text { Diğer markalardan önce bu }(\mathrm{X}) \\
\text { markayı satın almayı düşünürüm }\end{array}$ & 3,1849 & 1,31185 & ,791 & \multirow{4}{*}{2,902} & \multirow{4}{*}{72,541} & \multirow{4}{*}{0,873} \\
\hline $\begin{array}{l}\text { Diğer markaların özellikleri bu (X) } \\
\text { marka kadar iyi olsa bile yine bu } \\
\text { markayı tercih ederim }\end{array}$ & 2,9370 & 1,28945 & ,874 & & & \\
\hline $\begin{array}{l}\text { Diğer markalar daha iyi teklifler } \\
\text { önerse de yine bu (X) markayı tercih } \\
\text { ederim }\end{array}$ & 2,8235 & 1,34790 & ,863 & & & \\
\hline $\begin{array}{l}\text { Daha sonraki satın alımlarda yine bu } \\
\text { (X) markayı tercih ederim }\end{array}$ & 3,2059 & 1,28758 & 876 & & & \\
\hline \multicolumn{7}{|c|}{ MARKAYA DUYULAN GÜVEN(KMO:0,938) (Bartlett's/Chi-Square:1864,14 Sig:0,000) } \\
\hline $\begin{array}{l}\text { X markası beklentilerimi karşılayan } \\
\text { bir markadır. }\end{array}$ & 3,2731 & 1,24142 & ,829 & & & \\
\hline $\mathrm{X}$ markasına güven duyarım & 3,3908 & 1,20242 & 895 & & & \\
\hline
\end{tabular}




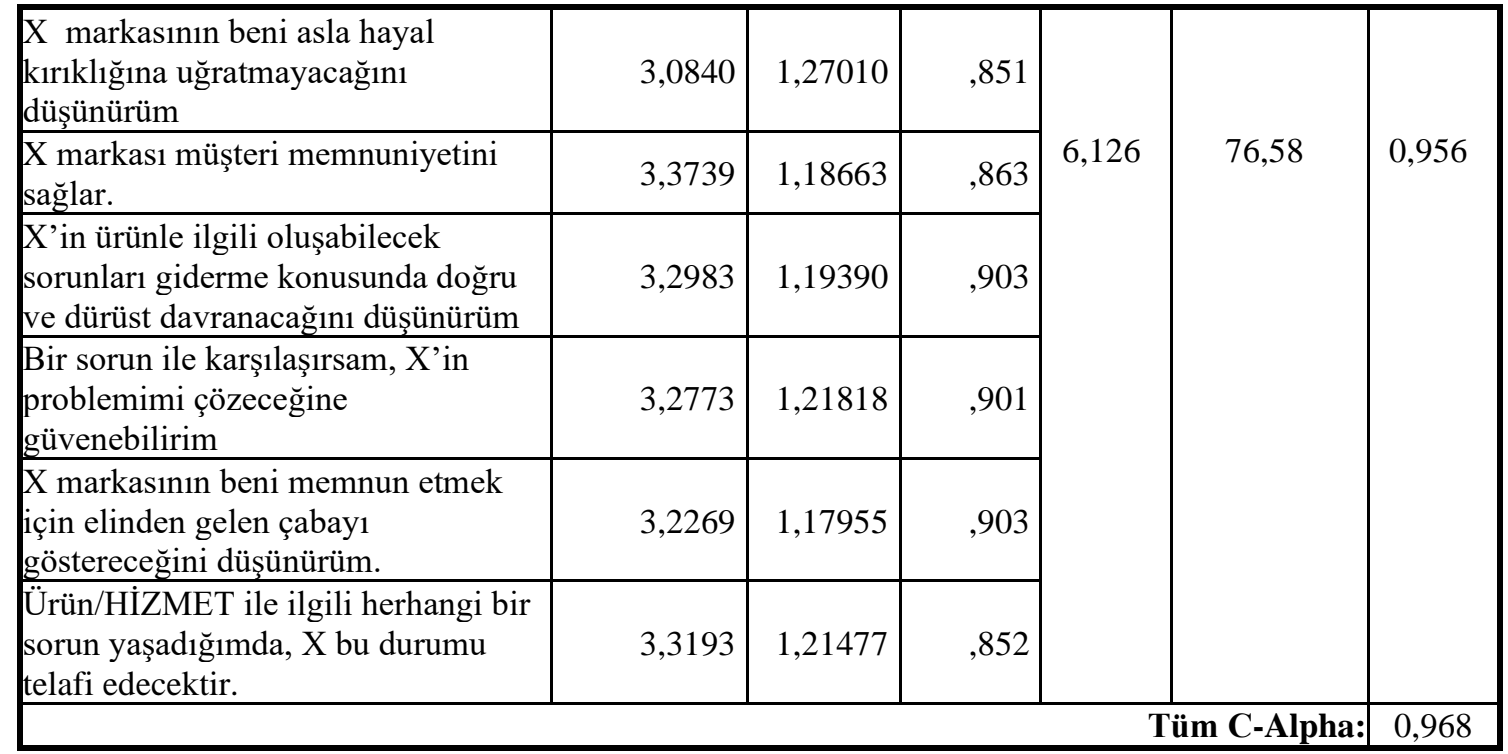

Araştırmada kullanılan ölçeklerin faktör yapılarını belirlemek için öncelikle açıklayıcı faktör analizi yapılmıştır. Faktör analizi işlemi yapılmadan önce verilerin faktör analizine uygun olup olmadığının ve örneklem büyüklüğünün faktör analizi için yeterli olup olmadığının belirlenmesi amacıyla KMO ve Bartlett'ın Küresellik testi sonuçlarına bakılmış(Algılanan Sosyal Medya Pazarlama Çabaları/Aktiviteleri (Kmo:0,930) (Bartlett's/Chi-Square:2127,08 Sig:0,000); Marka Tercihi (Kmo:0,788) (Bartlett's/Chi-Square:502,02 Sig:0,000) Ve Markaya Duyulan Güven(Kmo:0,938) (Bartlett's/Chi-Square:1864,14 Sig:0,000) ve araştırmadaki ölçeklerin faktör analizi yapmak için uygun olduğunu ve örnek büyüklüğünün bu analiz için yeterli olduğunu tespit edilmiştir. Analiz sonucunda ölçeklerin her biri(Algılanan Sosyal Medya Pazarlama Çabaları/Aktiviteleri, Marka Tercihi Ve Markaya Duyulan Güven) tek bir gizil değişken altında toplanmış ve tek faktörlü bir yapı göstermiştir. Tüm gizil değişkenlere(Algılanan Sosyal Medya Pazarlama Çabaları/Aktiviteleri(0,759-0,869), Marka Tercihi(0,791-0,876) Ve Markaya Duyulan Güven(0,829-0,903)) ait faktör yükü katsayılarının referans değer olan 0,600'nin üzerinde olduğu görülmektedir. Ölçeklerin faktör değerleri tespit edildikten sonra gizil değişkenler arasındaki korelasyon değerleri ile tanımlayıcı istatistikler aşağıdaki tabloda verilmiştir.

Tablo 2: Tanımlayıcı istatistikler ve değişkenler arasındaki korelasyon değerleri

\begin{tabular}{|l|c|c|c|c|c|}
\hline Gizil Değişkenler & $\mathbf{( 1 )}$ & $\mathbf{( 2 )}$ & $\mathbf{( 3 )}$ & Ortalama & S.Sapma \\
\hline $\begin{array}{l}\text { S.Medya Pazarlama Çabaları } \\
\text { (1) }\end{array}$ & 1 & & & 3,07 & 1,05 \\
\hline Markaya Duyulan Güven (2) & 0,697 & 1 & & 3,28 & 1,06 \\
\hline Marka Tercihi (3) & 0,706 & 0,815 & 1 & 3,04 & 1,11 \\
\hline
\end{tabular}

Tablo 2 de görüldüğg̈ üzere araştırma modelinde tanımlanan gizil değişkenler arasında yüksek ilişki olduğu tespit edilmiştir.

\section{PLS Yapısal Eşitlik Modellemesi ile Faktör Analizi ve Ölçüm Modelinin Test Edilmesi}

PLS, özellikle küçük çaplı örneklemlerde, örneklemin normal dağılım göstermediği durumlarda, bağımlı değişkeni en yüksek seviyede açıklamaya yarayan ve ölçüm hatalarını baz alması 
yönlerinden güçlü bir yaklaşımdır (Hair vd, 2014: 8). Ölçüm modelinin kabul edilmesi için bazı koşulların sağlanması gerekir. Bunlar İndikatör Güvenirliği, iç tutarlılık güvenirliği Birleşme ve Ayrışama geçerliliğinin sağlanmasıdır. Ölçüm modeli testinde indikatör güvenilirliği için faktör yüklerinin 0.700 üzeri olması, iç tutarlılık güvenilirliğinde Cronbach alpha, rho_A ve Composite Reliability(CR)değerinin 0.700 üzerinde olması, birleşme geçerliliği analizinde AVE değerinin 0.500 üzerinde olması ve yine ayrışma geçerliliğinde Heterotrait-Monotrait Ratio (HTMT) değerin 0.900 den az olması istenir. Bununla birlikte PLS ile analizde literatürde önerilen raporlanması gereken değerler araştırmanın genel durumu dikkate alınarak değerlendirilmelidir (Sarstedt vd, 2017: 430-441).

Baron ve Kenny (1986: 1180)'e göre aracı analizinde; ilk olarak bağımsız değişken ile bağımlı değişken arasında istatistiksel olarak anlamlı bir ilişki olmalıdır, 2.adımda bağımsız değişken ile aracı değişken arasında istatistiksel olarak anlamlı bir ilişki olmalıdır,3. Adımda aracı değişken ile bağımlı değişken arasında (bağımsız değişken ile birlikte model içerisinde kullanıldığında) istatistiksel olarak anlamlı bir ilişki olmalıdır ve 4. Adımda sadece bağımsız değişkenin bulunduğu modelde bağımsız değişkenin katsayısı (c) (mutlak değer olarak), bağımsız değişken ve aracı değişkenin bulunduğu modeldeki bağımsız değişkene ait katsayıdan (c') daha büyük olmalıdır. Bu 4 etkinin varlığı aracı değişkenin bağımsız değişkenle bağımlı değişken arasında aracılık etkisini ortaya koymaktadır.

\section{Aracı Değişkenin (Markaya Duyulan Güven) Modelden Çıkarılmış Hali ile Ölçüm Modelinin}

Testi

Aşağıda Tablo 3’te ölçüm modelinin analiz sonuçları sunulmuştur.

Tablo 3: Aracı değişkenin modele dahil edilmediği durumda ölçüm modelinin sonuçları, geçerlilik ve

\begin{tabular}{|c|c|c|c|c|c|c|}
\hline $\begin{array}{l}\text { Gizil } \\
\text { Değişkenler }\end{array}$ & $\begin{array}{l}\text { Ölçek } \\
\text { İndikatörleri }\end{array}$ & $\begin{array}{l}\text { Ölçek } \\
\text { İndikatö } \\
\text { rleri } \\
\text { Faktör } \\
\text { Yükleri } \\
\end{array}$ & $\begin{array}{l}\text { Cronbach's } \\
\text { Alpha }\end{array}$ & rho_A & $\begin{array}{l}\text { Composite } \\
\text { Reliability }\end{array}$ & $\begin{array}{l}\text { Average } \\
\text { Variance } \\
\text { Extracted } \\
\text { (AVE) }\end{array}$ \\
\hline \multirow{12}{*}{$\begin{array}{l}\text { Algilanan } \\
\text { Sosyal } \\
\text { Medya } \\
\text { Pazarlama } \\
\text { Çabalar1/ } \\
\text { Aktiviteleri }\end{array}$} & PC_Eglence1 & 0.807 & \multirow[t]{11}{*}{0.873} & \multirow[t]{11}{*}{0.878} & \multirow[t]{11}{*}{0.913} & \multirow[t]{11}{*}{0.725} \\
\hline & PC_Eglence2 & 0.867 & & & & \\
\hline & PC_Etkilesim1 & 0.821 & & & & \\
\hline & PC_Etkilesim2 & 0.841 & & & & \\
\hline & PC_Etkilesim3 & 0.839 & & & & \\
\hline & PC_KKiletisim1 & 0.831 & & & & \\
\hline & PC_KKiletisim2 & 0.767 & & & & \\
\hline & PC_Kisisellk1 & 0.771 & & & & \\
\hline & PC_Kisisellk2 & 0.792 & & & & \\
\hline & PC_Moda1 & 0.793 & & & & \\
\hline & PC_Moda2 & 0.809 & & & & \\
\hline & Tercih1 & 0.785 & 0.949 & 0.950 & 0.955 & 0.661 \\
\hline
\end{tabular}




\begin{tabular}{|c|c|c|}
\hline Marka & Tercih2 & 0.878 \\
\hline Tercihi & Tercih3 & 0.870 \\
\hline & Tercih4 & 0.869 \\
\hline
\end{tabular}

Tablo 4: Aracı Değişkenin modele dahil edilmediği durumda ayrışma geçerliliğinin kontrolü için Fornell-Larcker ve Heterotrait-Monotrait Ratio (HTMT) kriter analizi

\begin{tabular}{|l|l|l|}
\hline Fornell-Larcker & Marka Tercihi & $\begin{array}{l}\text { Algllanan Sosyal Medya } \\
\text { Aktiviteleri }\end{array}$ \\
\hline Marka Tercihi & $\mathbf{0 . 8 5 2}$ & \\
\hline Algılanan Sosyal Medya Aktiviteleri & 0.713 & $\mathbf{0 . 8 1 3}$ \\
\hline Heterotrait-Monotrait Ratio (HTMT) & Marka Tercihi & $\begin{array}{l}\text { Algllanan Sosyal Medya } \\
\text { Aktiviteleri }\end{array}$ \\
\hline Marka Tercihi & & \\
\hline Algilanan Sosyal Medya Aktiviteleri & 0.766 & \\
\hline
\end{tabular}

\section{Aracı Değişkenin (Markaya Duyulan Güven) Modele dahil edilmiş Hali ile Ölçüm Modelinin}

Testi

Aşağıda Tablo 5'te ölçüm modelinin analiz sonuçları sunulmuştur.

Tablo 5: Aracı değişkenin modele dahil edildiği durumda ölçüm modelinin sonuçları, geçerlilik ve güvenilirliği

\begin{tabular}{|c|c|c|c|c|c|c|}
\hline $\begin{array}{l}\text { Gizil } \\
\text { Değişkenler }\end{array}$ & $\begin{array}{l}\text { Ölçek } \\
\text { İndikatörleri }\end{array}$ & $\begin{array}{l}\text { Ölçek } \\
\text { İndikatörleri } \\
\text { Faktör } \\
\text { Yükleri }\end{array}$ & $\begin{array}{l}\text { Cronbach's } \\
\text { Alpha }\end{array}$ & rho_A & $\begin{array}{l}\text { Compo } \\
\text { site } \\
\text { Reliabi } \\
\text { lity }\end{array}$ & $\begin{array}{l}\text { Average } \\
\text { Variance } \\
\text { Extracted } \\
\text { (AVE) }\end{array}$ \\
\hline \multirow{11}{*}{$\begin{array}{l}\text { Alglanan } \\
\text { Sosyal } \\
\text { Medya } \\
\text { Pazarlama } \\
\text { Çabaları/ } \\
\text { Aktiviteleri }\end{array}$} & PC_Eglence1 & 0.803 & \multirow[t]{11}{*}{0.949} & \multirow[t]{11}{*}{0.949} & \multirow[t]{11}{*}{0.955} & \multirow[t]{11}{*}{0.661} \\
\hline & PC_Eglence2 & 0.864 & & & & \\
\hline & PC_Etkilesim1 & 0.820 & & & & \\
\hline & PC_Etkilesim2 & 0.841 & & & & \\
\hline & PC_Etkilesim3 & 0.844 & & & & \\
\hline & PC_KKiletisim1 & 0.829 & & & & \\
\hline & PC_KKiletisim2 & 0.759 & & & & \\
\hline & PC_Kisisellk1 & 0.770 & & & & \\
\hline & PC_Kisisellk2 & 0.791 & & & & \\
\hline & PC_Moda1 & 0.802 & & & & \\
\hline & PC_Moda2 & 0.817 & & & & \\
\hline \multirow{9}{*}{$\begin{array}{l}\text { Markaya } \\
\text { Duyulan } \\
\text { Güven }\end{array}$} & Guven1 & 0.832 & \multirow[t]{8}{*}{0.956} & \multirow[t]{8}{*}{0.956} & \multirow[t]{8}{*}{0.963} & \multirow[t]{8}{*}{0.766} \\
\hline & Guven2 & 0.896 & & & & \\
\hline & Guven3 & 0.851 & & & & \\
\hline & Guven4 & 0.862 & & & & \\
\hline & Guven5 & 0.902 & & & & \\
\hline & Guven6 & 0.899 & & & & \\
\hline & Guven7 & 0.903 & & & & \\
\hline & Guven8 & 0.852 & & & & \\
\hline & Tercih1 & 0.790 & 0.873 & .880 & 0.913 & 0.725 \\
\hline
\end{tabular}




\begin{tabular}{|l|l|l|l|l|l|l|}
\hline \multirow{2}{*}{$\begin{array}{l}\text { Marka } \\
\text { Tercihi }\end{array}$} & Tercih2 & 0.874 & \multirow{4}{*}{} & & & \\
\cline { 2 - 3 } & Tercih3 & 0.856 & & & & \\
\cline { 2 - 3 } & Tercih4 & 0.884 & & & & \\
\hline
\end{tabular}

Tablo 3 ve Tablo 5 de hem aracı değişkenin dahil edildiği hemde dahil edilmediği durumlardaki indikatör güvenilirliği için değerlendirilen Faktör yüklerinin tamamı referans değer olan 0.700 değerinin üzerindedir. Buradan hareketle tüm gizil değişkenlere ait Faktör yükleri 0.700 ve üzerinde olduğundan modele dahil indikatörlerin güvenilir olduğu söylenebilir. İç tutarl1lık güvenilirliği için hesaplanan Cronbach's Alpha, rho_A ve Composite Reliability değerleri sonuçları Tablo 3 ve Tablo 5 de incelendiğinde 0.700 eşik değerin üzerinde olduğu için modele dahil gizil değişkenlerin iç tutarlılık güvenilirliklerinin yeterli olduğu söylenebilir.

Tablo 3 ve Tablo 5 de hem aracı değişkenin dahil edildiği hemde dahil edilmediği durumlardaki de Birleşme Geçerliliği ölçen AVE değerleri incelendiğinde 0.500 eşik değerinin üzerinde olduğundan modeldeki gizil değişkenlerin birleşme geçerliliğini sağlandığını söylemek mümkündür.

Ayrışma geçerliliği için ise, Fornell ve Larcker ortaya attığı AVE değerlerinin karekökü, ilgili değişkenin diğer değişkenlerle olan korelâsyonlarından daha büyük olması istenen bir yöntem kullanılmaktadır. Yine ayrışma geçerliliğinin analizi için Heterotrait-Monotrait Ratio (HTMT) değerinin 0.900 referans değerinden düşük olması istenmektedir. (Sarstedt, vd,. 2017: 430-441). Ayrışma geçerliliğine ilişkin sonuçlar Tablo 4 ve Tablo 6'da sunulmuştur

Tablo 6: Aracı değişkenin modele dahil edildiği durumda ayrışma geçerliliğinin kontrolü için FornellLarcker ve Heterotrait-Monotrait Ratio (HTMT) kriter analizi

\begin{tabular}{|l|l|l|l|}
\hline Fornell-Larcker & $\begin{array}{l}\text { Markaya } \\
\text { Duyulan Güven }\end{array}$ & Marka Tercihi & $\begin{array}{l}\text { Algllanan Sosyal Medya } \\
\text { Aktiviteleri }\end{array}$ \\
\hline Markaya Duyulan Güven & $\mathbf{0 . 8 7 5}$ & & \\
\hline Marka Tercihi & 0.819 & $\mathbf{0 . 8 5 2}$ & \\
\hline Alg1lanan Sosyal Medya Aktiviteleri & 0.705 & 0.708 & $\mathbf{0 . 8 1 3}$ \\
\hline $\begin{array}{l}\text { Heterotrait-Monotrait Ratio } \\
\text { (HTMT) }\end{array}$ & $\begin{array}{l}\text { Markaya } \\
\text { Duyulan Güven }\end{array}$ & Marka Tercihi & $\begin{array}{l}\text { Algilanan Sosyal Medya } \\
\text { Aktiviteleri }\end{array}$ \\
\hline Markaya Duyulan Güven & 0.893 & & \\
\hline Marka Tercihi & 0.733 & 0.766 & \\
\hline Algllanan Sosyal Medya Aktiviteleri & 0.73 & \\
\hline
\end{tabular}

Tablo 4 ve Tablo 6 da görüldüğü üzere hem aracı değişkenin dahil edildiği hem de dahil edilmediği durumlardaki modelin ayrışma geçerliliği için incelendiğinde Fornell-Larcker koyu yazılan AVE değerlerinin kareköklerinin değişkenler arası korelasyon katsayılarından büyük olduğundan Fornell-Larcker kriterinin sağlandığı görülmektedir. Ayrıca ayrışma geçerliliği için çapraz yükler analiz edilmiştir. İndikatörlerin her birisinin ait olduğu değişkende en yüksek faktör yüküne sahip olduğu görülmüştür. Yine ayrışma geçerliliği için Tablo 4 Ve Tablo 6 da Heterotrait-Monotrait Ratio (HTMT) değerine bakılmış tüm sonuçların kritik değer olan 0.900 altında olduğu görülmüştür(Doğan, 2019: 101- 
105). Ölçüm modelinin Ayrışma geçerliliğine sahip olduğu söylenebilir. Yapılan analizler sonucunda Ölçüm modelinin iç tutarlılık ve birleşme güvenilirliğine sahip olduğu aynı zamanda ölçüm modelinin ayrışma ve birleşme geçerliliğine sahip olduğu ve ölçüm modelinin geçerli olarak kabul edilebilir olduğu söylenebilir.

Veri ile model uyumu için uyum indis sonuçlarına bakılmalıdır. Aracı Değişkenin modele dahil edilmediği model testinde; toplam örneklem için uygulanan modelin uyum indis değerleri; CMIN değeri: 471,405; NFI: 0,841; SRMR: 0,063 (Referans Değerler:NFI $>0.800 ; \quad$ SRMR $<0.080$ Karagöz,2019)olarak görülmekte ve tüm uyum indisleri model ile örneklem arasında iyi bir uyumun olduğunu göstermektedir. Aracı Değişkenin modele dahil edildiği model testinde; Model testine geçmeden önce Örneklem ile model arasındaki uyuma bakılmalıdır. Toplam örneklem için uygulanan modelin uyum indis değerleri; CMIN değeri: 864,515; NFI: 0,841; SRMR: 0,059 (Referans Değerler:NFI $>0.800$; SRMR $<0.080$ Karagöz, 2019: 51-72)olarak görülmekte ve tüm uyum indisleri model ile örneklem arasında iyi bir uyumun olduğunu göstermektedir.

İlişki analizine geçilmeden önce endojen değişkenlerin hemde egzojen değişkenleri ile arasında doğrusallık olmadığını kontrol etmek için hem indikatörlerin hem de değişkenlerin VIF değerlerine bakılmıştır. Aracı Değişkenin modele dahil edilmediği modelde Algılanan Sosyal medya çabaları egzojen değişkeni (VIF:1.000) olduğundan doğrusallık problemi olmadığı (VIF<5.00 Doğan,2019) görülmüştür. Aracı Değişkenin modele dahil edildiği modelde ise Algılanan Sosyal medya çabaları egzojen değişkeni (VIF:1.000) ile markaya duyulan güven değişkeni (VIF:1.000) olduğundan doğrusallık problemi olmadığı (VIF<5.00 Doğan, 2019: 101-105) görüldüğünden model testine geçilebilmektedir.

\section{Yapısal Modelin Test Edilmesi}

Araştırma modelindeki etkilerin test edilmesi ve anlamlılığı $\mathrm{t}$ değerleri üzerinden hesaplanmaktadır. Wong (2013: 20) göre, $\mathrm{t} \geq 1,96$ ise \%95 düzeyinde anlamlılık eğer $\mathrm{t} \geq 2,58$ ise \%99 düzeyinde anlamlılıktan söz edilmektedir. SmartPLS'de $t$ değerleri Bootstrapping işlemi gerçekleştirildikten sonra hesaplanmaktadır.

Baron ve Kenny (1986) yaklaşımına göre aracılık etkisi incelenirken ilk olarak aracı değişken modelden çıkarılarak başlandığından dolayı, ilk olarak modelden aracı değişken çıkarılarak oluşturulan model test edilecektir.

\section{Aracı Değişken Çıkarılmış Yapısal Modelin Analizi}

Aşağıda Şekil 2'de yapısal modelin analizi sunulmuştur. Aracı Değişken Çıkarılmış Yapısal Modelin Pls Analiz Sonucu Tablo 7'de verilmiştir. 


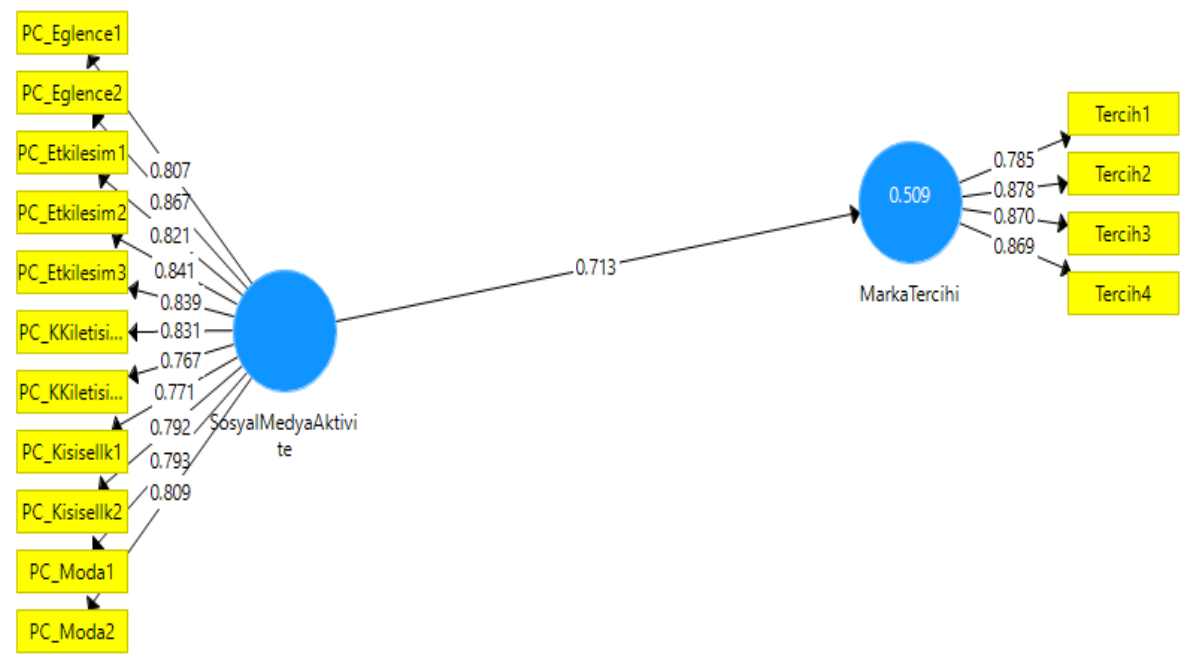

Şekil 2: Aracı Değişken Çıkarılmış Yapısal Modelin Analizi

Tablo 7: Aracı değişken çıkarılmış yapısal modelin Pls analiz sonucu

\begin{tabular}{|l|l|l|l|l|l|l|l|}
\hline \multicolumn{2}{|l|}{ Bağımlı Değişken: Marka Tercihi } \\
\hline Bağımsız Değişken & $\begin{array}{l}\text { Std. } \\
\text { Beta }\end{array}$ & $\begin{array}{l}\text { Std. } \\
\text { Hata }\end{array}$ & $\mathbf{t}$ değeri & $\begin{array}{l}\text { Anlamlılık } \\
\mathbf{\% 9 9}\end{array}$ & $\mathbf{f}^{2}$ & $\mathbf{R}^{2}$ & Hipotez \\
\hline $\begin{array}{l}\text { Algılanan Sosyal } \\
\text { Medya Pazarlama } \\
\text { Çabaları } \\
\text { /Aktiviteleri }\end{array}$ & 0.713 & 0.042 & 17.184 & $\mathbf{0 . 0 0 0}$ & $\mathbf{1 . 0 3 6}$ & $\mathbf{0 . 5 0 9}$ & H3a \\
\hline
\end{tabular}

Tablo 7 incelendiğinde, algılanan sosyal medya pazarlama aktivitelerinin tüketicinin marka tercihi üzerinde anlamlı ve pozitif etkilerinin olduğu görülmektedir. Değişkenin $\mathrm{t}$ değerleri incelendiğinde, değerin de 2,58 'in üzerinde olduğundan algilanan sosyal medya pazarlama aktivitelerinin tüketicinin marka tercihi üzerindeki etkilerinin 0,01 düzeyinde anlamlı olduğu göstermektedir. Ayrıca, bağımsız değişkenin(Algılanan Sosyal Medya Pazarlama Çabaları /Aktiviteleri) bağımlı değişkenin(Marka Tercihi) açıklama gücüne katkısını belirlemek amacıyla ${ }^{2}$ değerleri incelenmiştir. $f^{2}$ değişkeni 0,02 ve üzerinde ise bağımsız değişkenin etkisinin küçük olduğu, 0,15 ve üzerinde ise orta düzeyde etki ve 0,35 'in üzerinde ise büyük düzeyde etkiden söz edilmektedir (Doğan, 2019:101). Bu durumda, algılanan sosyal medya pazarlama aktivitelerinin tüketicinin marka tercihi üzerindeki etkisinin büyük düzeyde olduğu anlaşılmaktadır.

Sonuç olarak, yapılan analizler neticesinde H3a (Tüketicilerin algıladıkları sosyal medya pazarlama çabalarının marka tercihi üzerinde anlamlı, pozitif ve direkt bir etkisi vardır.) hipotezi desteklenmiştir. 
Aracı Değişkenin modele dahil edildiği Yapısal Modelin Pls Analiz Sonucu Tablo 8'de verilmiştir.

Tablo 8: Aracı Değiş̧kenin Modele Dahil Edildiği Yapısal Modelin Pls Analiz Sonucu

\begin{tabular}{|c|c|c|c|c|c|c|c|}
\hline \multicolumn{7}{|c|}{ Bağımlı Değişken: Marka Tercihi } & \multirow[b]{2}{*}{ Hipotez } \\
\hline Bağımsız Değişken & $\begin{array}{l}\text { Std. } \\
\text { Beta }\end{array}$ & $\begin{array}{l}\text { Std. } \\
\text { Hata }\end{array}$ & t değeri & $\begin{array}{l}\text { Anlamlılık } \\
\% 99\end{array}$ & $\mathbf{f}^{2}$ & $\overline{\mathbf{R}^{2}}$ & \\
\hline Markaya Duyulan Güven & 0.819 & 0.026 & 31.247 & 0.000 & 2.042 & 0.497 & $\mathbf{H 2}$ \\
\hline \multicolumn{7}{|c|}{ Bağımlı Değişken: Markaya Duyulan Güven } & \\
\hline Bağımsız Değişken & $\begin{array}{l}\text { Std. } \\
\text { Beta }\end{array}$ & $\begin{array}{l}\text { Std. } \\
\text { Hata }\end{array}$ & t değeri & $\begin{array}{l}\text { Anlamlılık } \\
\% 99\end{array}$ & $\mathbf{f}^{2}$ & $\overline{\mathbf{R}^{2}}$ & Hipotez \\
\hline $\begin{array}{l}\text { Algilanan Sosyal Medya } \\
\text { Aktiviteleri }\end{array}$ & 0.705 & 0.046 & 15.368 & 0.000 & 0.986 & 0.671 & H1 \\
\hline \multicolumn{7}{|c|}{ Bağımlı Değişken: Marka Tercihi } & \\
\hline $\begin{array}{l}\text { Bağımsız Değişken Aracı } \\
\text { Değişken Üzerinden }\end{array}$ & $\begin{array}{l}\text { Std. } \\
\text { Beta }\end{array}$ & $\begin{array}{l}\text { Std. } \\
\text { Hata }\end{array}$ & t değeri & $\begin{array}{l}\text { Anlamlılık } \\
\% 99\end{array}$ & & & Hipotez \\
\hline $\begin{array}{l}\text { Algılanan Sosyal Medya } \\
\text { Pazarlama Çabaları Ð } \\
\text { Markaya Duyulan Güven }\end{array}$ & 0.577 & 0.050 & 11.451 & 0.000 & & & H3b \\
\hline
\end{tabular}

H1: Tüketicilerin algıladıkları sosyal medya pazarlama çabalarının tüketicilerin markaya duydukları güven üzerinde anlamlı ve pozitif etkisi vardır.

H2: Tüketicilerin markaya duydukları güven düzeyinin marka tercihi üzerinde anlamlı ve pozitif etkisi vardir.

H3b: Tüketicilerin algıladıkları sosyal medya pazarlama çabalarının Tüketicilerin markaya duydukları güven düzeyi üzerinden (Aracılık Etkisi) marka tercihi üzerinde anlamlı bir etkisi vardır.

Tablo 8 incelendiğinde, Tüketicilerin algıladıkları sosyal medya pazarlama çabalarının tüketicilerin markaya duydukları güven üzerinde anlamlı ve pozitif, Tüketicilerin markaya duydukları güven düzeyinin marka tercihi üzerinde anlamlı ve pozitif ve Tüketicilerin algıladıkları sosyal medya pazarlama çabalarının Tüketicilerin markaya duydukları güven düzeyi üzerinden (Aracılık Etkisi) marka tercihi üzerinde anlamlı bir etkilerinin olduğu görülmektedir. Her üç ilişkinin $t$ değerleri incelendiğinde, üç değerin de 2,58'in üzerinde olduğu ve etkilerin 0,01 düzeyinde anlamlı olduğu görülmektedir. Ayrıca, bağımsız değişkenin(Markaya Duyulan Güven) bağımlı değişkenin(Marka Tercihi) ve bağımsız değişkenin(Algılanan Sosyal Medya Aktiviteleri) bağımlı değişkenin(Markaya Duyulan Güven) açıklama gücüne katkısını belirlemek amacıyla $\mathrm{f}^{2}$ değerleri $(2,042$ ve 0,986$)$ incelenmiş, algılanan sosyal medya pazarlama aktivitelerinin markaya duyulan güven ve markaya duyulan güvenin marka tercihi üzerindeki etkilerinin büyük düzeyde olduğu anlaşılmaktadır.

Sonuç olarak, yapılan analizler neticesinde H1(Tüketicilerin algıladıkları sosyal medya pazarlama çabalarının tüketicilerin markaya duydukları güven üzerinde anlamlı ve pozitif etkisi vardır.), H2 (Tüketicilerin markaya duydukları güven düzeyinin marka tercihi üzerinde anlamlı ve pozitif etkisi vardır.) ve H3b(Tüketicilerin algıladıkları sosyal medya pazarlama çabalarının Tüketicilerin markaya 
duydukları güven düzeyi üzerinden (Aracılık Etkisi) marka tercihi üzerinde anlamlı bir etkisi vardır.) hipotezleri desteklenmiştir.

Baron ve Kenny (1986) göre, aracılık etkisinin var olup olmadığının tespitinde Variance Account For (VAF) değerinin kullanılmasını öngörmektedirler. Aracı etkinin yüzdeliğini hesaplayarak kullanılan VAF değeri; aracı değişkenin modele dahil olmadığı ilişki katsayısının aracı değişken modelde iken elde edilen dolaylı etki değerine bölünerek hesaplanılmaktadır. Hesaplanan VAF değeri 0.20 değerinden az ise arac1 etki olmadığ, $0.20<\mathrm{VAF}<0.80$ ise kismi aracılık etkisi olduğu ve $\mathrm{VAF}>0.80$ ise tam aracılık etkisinden söz edilmektedir. Modelden elde edilen VAF değeri: $0.577 / 0.713=0.81$ olduğundan markaya duyulan güvenin sosyal medya pazarlama aktivitelerinin marka tercihi üzerinde etkisinde tam aracılığa sahip olduğu söylenebilir.

Aracılık analizinde yapısal model, Baron ve Kenny (1986) yöntemi ile test edilerek VAF değeri incelenmiştir. Bu kapsamda, Baron ve Kenny (1986) yönteminin tüm adımları test edilmiş ve aracılık etkisinin varlığı bulgulanmıştır.

\section{Sonuç ve Tartışma}

Günümüz rekabet şartlarında işletmeler varlığını sürdürebilmek için sosyal medyada yer almak durumundadırlar. Zira rekabetin her geçen gün arttığı bir ortamda mal ve hizmetler de çok fazla sayıda işletme tarafından üretilmektedir. Böyle bir durum işletmelerin rakiplerinden ayrılarak kendini, mal ve hizmetlerini farklılaştıracak mecralarda pazarlama çabaları içerisinde bulunması ihtiyacını ortaya çıkarmıştır.

Sosyal medyada var olma nedeni işletmenin farklı ortamlarda bulunan tüketiciyi anlamak, dinlemek ve anlık gereksinimlere cevap vermek ile birlikte yeni pazar arayışı, mal ve hizmet tanıtımı, satış, halkla ilişkiler ve reklam çabalarını sunma firsatı vermiştir. İşletmeler sosyal medyayı etkin kullanarak işletmenin imajına olumlu katkılarının yanı sıra tüketicilerle uzun vadeli ilişkiler kurarak marka güveni sağlaması dolayısıyla da marka tercihinin kendisi lehine şekillenmesini sağlayabilmektedirler. İşletmeler bunu yaparken geleneksel iletişim alanları kadar en az sosyal medya ağlarına da gerekli olan önemi vermesi gerekir. Dolayısıyla bu alanda etkili bir pazarlama çabası içerisinde bulunarak işletmelerin varlıklarını sürdürmeleri önemli bir husustur.

Çalışmada sosyal medya üzerinden yapılan pazarlama çabalarının markaya duyulan güven ve marka tercihi üzerindeki etkisinin ortaya konulması amaçlanmıştır. $\mathrm{Bu}$ amaçla yapılan araştırma sonuçlarına göre tüketicilerin algıladıkları sosyal medya pazarlama çabalarının tüketicilerin markaya duydukları güven üzerinde anlamlı ve pozitif etkisi olduğu, tüketicilerin markaya duydukları güven düzeyinin marka tercihi üzerinde anlamlı ve pozitif etkisi olduğu tespit edilmiştir. Marka tercihi üzerinde sosyal medya çabalarının pozitif etkisinin olması Kim ve Ko (2012), Göktaş ve Tarakçı (2018) 
ile Karayalçın (2019) yaptıkları çalışmalarıyla örtüşmektedir. Ayrıca tüketicilerin algıladıkları sosyal medya pazarlama çabalarının marka tercihi üzerinde anlamlı, pozitif ve doğrudan bir etkisi olduğu ve tüketicilerin algıladıkları sosyal medya pazarlama çabalarının tüketicilerin markaya duydukları güven düzeyi üzerinden (aracılık etkisi) marka tercihi üzerinde anlamlı bir etkisi olduğu belirlenmiştir. $\mathrm{Bu}$ sonuç Chaudhuri ve Holbrook (2001) çalışmaları ile benzeşmektedir.

Marka tercihini kendisine yöneltmek isteyen markaların algılanan soysal medya pazarlama çabalarına yatırım yapmaları aynı zamanda markaya güven faktörünü göz önünde bulundurmaları durumunda başarılı olacakları söylenebilir. Sosyal medya pazarlama çabalarının markaya duyulan güven üzerindeki etkisini de böylece arttırmış olabileceklerdir. Nihai hedefleri marka tercihinde ulaşmalarında destekleyici bir faktör olacaktır.

İlgili literatür tarandığında işletmelerin sosyal medya üzerinden yapılan pazarlama aktivitelerinin markaya duyulan güven ve marka tercihi üzerindeki etkisine yönelik ve hizmet alanında GSM sektörü üzerinde uygulamaya yönelik bir çalışmaya rastlanmamış olması farklı açılardan mukayese edilmeye örnek nitelikte düşünülebilir. Ayrıca kullanılan yöntemler itibari ile başka bir çalışmanın da olmaması konunun önemini artıran diğer önemli bir husustur. Dolayısıyla çalışmanın literatüre katkı sağlayacağı düşünülmektedir.

Araştırmanın farklı demografik özelliklerdeki tüketiciler, sektörler ve farklı değişkenler eklenerek ile test edilerek ve daha geniş temsil yeteneğine sahip bir örneklem yöntemiyle kapsamının genişletilerek uygulanması araştırmacılar ve uygulayıcılar açısından anlamlı olacaktır.

Yazar Katkıları: Bu çalışmanın giriş, kavramsal çerçeve, sonuç ve tartışma bölümünde ikinci yazar, verilerin analizi ve bulgular bölümlerinde birinci yazar katkı sağlamıştır.

Çıkar Beyanı: Yazarlar arasında çıkar çatışması olmamıştır.

\section{Kaynakça}

Aktuğlu, I.K. ve Temel, A. (2006). Tüketiciler markalarını nasıl tercih ediyor? (Kamu sektörü çalışanlarının giysi markalarını tercihini etkileyen faktörlere yönelik bir araştırma), Selçuk Üniversitesi Sosyal Bilimler Enstitüsü Dergisi, 15, 43-59.

Baron, R. M. ve Kenny, D. A. (1986). The moderator-mediator variable distinction in social psychological research: Conceptual, strategic and statistical considerations, Journal of Personality and Social Psychology, 51, 1173-1182.

Bartels, D. M. ve Johnson, E. J. (2015). Connecting cognition and consumer choice. Cognition, 135, 4751.

Benett R. (1996), Relationship formation and governance in consumer markets: Transactual analysis versus the behaviorist aproach, Journal of Marketing Research, 12, 417-436.

Cesur, Z. ve Alnıaçık, Ü. (2019). Marka beğenilirliğinin marka tercihi üzerine etkisi: Cep telefonu sektöründe bir araştırma, Journal of Social and Humanities Sciences Research, 6 (44), 34843494.

Chang, H.H. ve Liu, Y.M. (2009). The impact of brand equity on brand preference and purchase intention in the services industries, The Service Industries Journal, 29 (12), 1687-1706. 
Chaudhuri, A. ve Holbrook, M. B. (2001).The chain of effects from brand trust and brand affects to brand performance: The role of brand loyalty, Journal of Marketing, 65, 81-93.

Coulter, K. S. ve Coulter, R. A. (2002). Determinants of trust in a service provider: The moderating role of length of relationship, Journal of Services Marketing, 16 (1), 35-50.

Delgado-Ballester, E. ve Munuera-Aleman, J. L. (2005). Does brand trust matter to brand equity?, Journal of Product and Brand Management, 14 (3), 187-196.

Distaso, M.W., Mccorkindale, T. ve Wright, D. K. (2011). How public relations executives perceive and measure the impact of social media in their organizations, Public Relations Reviews, 37(3), 325-328.

Doğan, D. (2019). Smart PLS ile veri analizi. 2.Bask1, Ankara: Zet Yayınları.

Doney, P. M. ve Cannon, J. P. (1997). Trust in buyer-seller relationships, Journal of Marketing, 61, 3551.

Godey, B., Manthiou, A., Pederzoli, D., Rokka, J., Aiello, G., Donvito, R. ve Singh, R. (2016). Social media marketing efforts of luxury brands: Influence on brand equity and consumer behavior, Journal of Business Research, 69, 5833-5841.

Göktaş, B. ve Tarakçı, İ. E. (2018). Bir tutundurma aracı olarak reklamın sosyal medyada uygulamalarına yönelik bir araştırma: Instagram örneği, Girişimcilik Inovasyon ve Pazarlama Araştırmaları Dergisi, 2(3), 50-67.

Hacıefendioğlu, Ş. ve Fırat, D. (2014). Sosyal medyada yer alan markalara ilişkin marka imajının güven üzerindeki etkisi, Kocaeli Üniversitesi Sosyal Bilimler Dergisi, 27, 87 - 96.

Hair J.F., Hult, G.T.M., Ringle, C.M. ve Sarstedt, M. (2014). A primer on Partial Least Squares Structural Equation Modeling (PLS-SEM), Sage Publication: Losangeles.

Hellier, P. K., Geursen, G. M., Carr, R. A. ve Rickard, J. A. (2003). Customer repurchase intention: A general structural equation model, European Journal of Marketing, 37 (12), 1762-1800.

Horppu, M., Kuıvalainen, O., Tarkiainen, A. ve Ellonen, H. K. (2008). Online satisfaction, trust and loyalty and the impact of the offline parent brand, Journal of Product and Brand Management, 17(6), 403-413.

Hwang, J. ve Chihyug, O. (2013). The antecedents and consequence of consumer attitudes toward restaurant brands: A comparative study between casual and fine dining restaurants, International Journal of Hospitality Management, 32, 121 -131.

İslamoğlu, A. H. ve Alnıaçık, Ü. (2016). Sosyal bilimlerde araştırma yöntemleri. Beta Yayınları: İstanbul.

Karagöz, Y. (2019). SPSS ve AMOS uygulamaları bilimsel araştırma yöntemleri ve yayın etiği, 2. Baskı, Ankara: Nobel Yayıncılık.

Karayalçın, C. (2019). Algılanan sosyal medya pazarlama çabalarının marka değeri ve satın alma niyeti üzerine etkisi: Tüketicilerin sosyal medya bağı ve kullanım sıklığı üzerine bir araştırma. Yayınlanmamış Doktora Tezi. Antalya: Akdeniz Üniversitesi. Sosyal Bilimler Enstitüsü.

Keiningham, T. L., Perkins-Munn, T., Aksoy, L. ve Estrin, D. (2005). Does customer satisfaction lead to profitability? The mediating role of share of wallet, Managing Service Quality, 15 (2), 172181.

Keskin, H.D. ve Yıldız, S. (2010). Tüketicilerin marka tercihlerinde etkili olan faktörler ile marka imajı’nın marka değeri üzerindeki etkileri: Trabzon örneği, Dumlupınar Üniversitesi Sosyal Bilimler Dergisi, 27, 239-254. 
Kim, A. J. ve Ko, E. (2012). Do social media marketing activities enhance customer equity? An empirical study of luxury fashion brand, Journal of Business Research, 65, 1480-1486.

Kwong, K. ve Wong, K. (2013). Partial Least Squares Structural Equation Modeling (PLS-SEM) Techniques Using Smartpls, Technical Note 1, Marketing Bulletin, 24, 1-32.

Lau, G. ve Lee, S.H. (1999). Consumers' trust in a brand and the link to brand loyalty, Journal of Market Focused Management, 4, 341-370.

Mathur, A., Moschis, G. P. ve Lee, E. (2003). Life events and brand, Journal of Consumer Behaviour, $3(2), 129-141$.

Memiş, S. ve Cesur, Z. (2016). Algılanan hizmet kalitesi ile marka bağlılığı ilişkisi şehirlerarası yolcu taşımacıllı̆ı yapan otobüs firmaları üzerine bir araştırma, CBÜ Sosyal Bilimler Dergisi, 14(2), 453-484.

Morgan, R. M. ve Hunt, S. D. (1994). The commitment-trust theory of relationship marketing, The Journal of Marketing, 58, 20-38.

Önen, V. (2018). Marka güveni marka sadakati ve marka tercihi arasındaki ilişkinin incelenmesi: Kırtasiye sektörü uygulaması, Işsetme Araştırmaları Dergisi, 10 (2), 609-626.

Punj, G.N. ve Hillyer, C.L. (2004). A cognitive model of customer-based brand equity for frequently purchased products: Conceptual framework and empirical results, Journal of Consumer Psychology, 14 (1), 124-131.

Roberts, J. H. ve Lattin, J. M. (1991). Development and testing of a model of consideration set composition, Journal of Marketing Research, 28 (4), 429-440.

Şahin, E. ve Gültekin, C. (2017). Markaya duyulan güven ve etnosentrik eğilimlerin marka sadakatine etkisi: Bir marka örneği, Süleyman Demirel Üniversitesi İktisadi ve İdari Bilimler Fakültesi Dergisi. 22 (4), 993-1012.

Sarstedh, M., Ringle, C.M. ve Hair, J.F. (2017). Partial least structural eduation modeling, Organizational Research Methods, 16 (3), 425-448.

Usta, R. ve Memiş, S. (2009). Hizmet kalitesi ve marka bağlılığı arasındaki ilişki üzerine müşteri tatmininin aracilık etkisi, Atatürk Üniversitesi İktisadi ve İdari Bilimler Dergisi, 23(4), 87108.

Uzunkaya,T. ve Yükselen, C. (2020). Lüks giyim markalarında sosyal medya ilgilenimi, marka değeri ve marka tercihi ilişkisi üzerine bir araştırma, Öneri Dergisi, 15 (53), 276-304. 